Tamara M. Alfirević, MA

Fakultet za pravne i poslovne studije „Dr Lazar Vrkatić”,

Katedra za engleski jezik

Novi Sad

osmehtvoj@gmail.com

\title{
UTICAJ IGRE NA UČENJE VOKABULARA ENGLESKOG JEZIKA UČENIKA DRUGOG I TREĆEG RAZREDA OSNOVNE ŠKOLE ${ }^{1}$
}

\begin{abstract}
Apstrakt
$\mathrm{U}$ ovom radu se razmatraju potreba i mogućnosti upotrebe igara $\mathrm{u}$ nastavi engleskog jezika u drugom i trećem razredu osnovne škole u našoj zemlji. Cilj rada je utvrditi u kojoj meri učenje reči kroz igru utiče na povećanje obima upamćenih pojmova i to putem istraživanja sprovedenog među učenicima osnovne škole. Istraživanje je obuhvatilo ukupno 66 učenika drugog i trećeg razreda, od kojih je u svakom od razreda jedno odeljenje bilo kontrolna, a drugo eksperimentalna grupa. Igra je prikazana kao jedna od mogućih tehnika savremene nastave kojom se povećava obim naučenog, aktivnost učenika na času i osećaj zadovoljstva u toku učenja stranog jezika. Rezultati istraživanja pokazuju da su učenici u čijoj se nastavi koristila igra za učenje vokabulara u znatoj meri unapredili svoj vokabular.
\end{abstract}

Ključne reči: vokabular, igra, engleski jezik, osnovna škola.

\section{UVOD}

Sve brojnija literatura iz oblasti metodike nastave stranog jezika ukazuje na to da tradicionalni pristup u nastavi više ne dovodi do značajnijeg napretka $u$ učenju. U savremenoj nastavi sa savremenim učenicima kao akterima neophodno je osmisliti takav nastavni proces koji omogućava učenicima različitih sposobnosti da budu ravnopravni učesnici, podstiče učenike na razmišljanje i samostalno

1 Rad je napisan na osnovu rezultata istraživanja koje je rađeno za potrebe izrade masterskog rada na temu „Uticaj igre na učenje vokabulara učenika drugog i trećeg razreda osnovne škole”. Rad je odbranjen na Fakultetu za pravne i poslovne studije, 9. jula 2014. godine, pred komisijom doc. dr Tatjana Glušac (mentor), prof. dr Vesna Pilipović i doc. dr Milan Živković. 
izvođenje zaključaka, kao i povezivanje učeničkog iskustva sa obrazovnim procesom. Sve što se radi na času trebalo bi da odgovara trenutnom znanju učenika i da bude usko povezano sa njihovim interesovanjima. Učenike bi trebalo podsticati na rad kroz niz manuelnih aktivnosti, crtanjem, pravljenjem, socijalnim aktivnostima, terenskim radom, posmatranjem i zaključivanjem; ocenjivao bi se napredak u odnosu na početno znanje, motivisanost za rad, aktivnost i razvoj ličnosti (Ivić, Pašikan \& Antić 2001), a sve u cilju razvoja ličnosti deteta.

Pri polasku u prvi razred, učitelji i roditelji često zanemaruju činjenicu da je dete samo par meseci ranije većinu vremena provodilo igrajući se i da nagli prelazak iz sistema igrovnih aktivnosti u sistem nastavnih aktivnosti, ne odgovara razvojnim mogućnostima deteta. Tada dolazi do problema na koje se većina učitelja današnjice žali - pažnja deteta slabi, ono ne radi zadatke, brzo zaboravlja, ustaje, vrpolji se i često pravi greške (Kopas-Vukašinović 2006). Dete koje je u predškolskoj ustanovi imalo dobre rezultate, može postati nezainteresovano u izvršavanju školskih obaveza. To se može objasniti na sledeći način: dok se igra, dete se maksimalno angažuje i koristi sva stečena iskustva. Igra čini da se dete oseti sigurno i motivisano, privlači mu pažnju i kroz nju dete razvija svoje sposobnosti. Sve to dete ne može da ispolji sedeći u klupi, pa se samim tim umanjuju i njegova motivacija i želja da učestvuje u školskim aktivnostima (Kopas-Vukašinović 2006).

Da bi se ublažio ovaj prelaz, bilo bi poželjno da se na kraju predškolskog perioda, a na početku školskog, napravi prelazni period u kom će se jedan deo aktivnosti odvijati kroz igru. Na taj način će se prevazići otpor prema školi. Igre koje mogu biti od koristi u ovom periodu su igre zvucima, gestovima, pokretom, dramatizacija, pa čak i kompjuterske igre (Kopas-Vukašinović 2006). Pomenute igre mogu se koristiti skoro bilo kad i za bilo koju temu. Neke od igara koje se mogu primenjivati su igre sa pokretom, igre sa imitacijom, igre rečima, muzičke igre, mimika itd. Štaviše, moderno doba i upotreba računara u savremenoj nastavi, otvaraju mnogobrojne mogućnosti za uključivanje igre u nastavne aktivnosti (Mirković 2007).

Značaj uključivanja igre u nastavu kao sredstva za razvijanje ličnosti deteta sve je uočljiviji. Ovakva nastava pomera fokus sa nastavnika na učenike. Učenici su okrenuti jedni drugima, ispoljavaju svoju maštu, misao, planiranje i inicijativu. Kroz igru deca stvaraju, ispoljavaju svoje osobine i ostvaruju kontakt sa drugom decom čime razvijaju svoje socijalne karakteristike (Mirković 2007).

Cilj igre u školi je da aktivira učenike i poboljša nastavni proces. Nastavnik igru može uključiti u bilo koji deo procesa učenja i za savladavanje različitih materija, a upravo to čini jednu od osnovnih vrednosti igre. Didaktički cilj se prikazuje kroz igru, nastavnik određuje pravila igre, nastavno gradivo predstavlja način na koji će se učenici igrati, a uspešno izvršavanje igre je povezano sa uspeš- 
nim savladavanjem zadatka (Mirković 2007). U skladu sa tim, možemo reći da se igra, kao aktivnost koja može da se prilagodi nastavnom planu i programu, a u isto vreme je zanimljiva i interesantna deci, savršeno uklapa u koncept savremene nastave.

U knjigama za engleski jezik kod nas, međutim, igre su predstavljene kao aktivnosti koje se mogu sprovoditi kao uvod u lekciju ili kao zanimljiva aktivnost ukoliko postoji višak vremena nakon završene lekcije, a vrlo često predložene igre nisu povezane sa materijalom koji se obrađuje na času. Igre, takođe, nisu predviđene nastavnim planom i programom, a postoje i mišljenja da su one suvišne za čas i da se njima gubi kontrola nad učenicima.

Stoga bi predmet istraživanja ovog rada bio na koji način i u kojoj meri bi igra na časovima engleskog jezika unapredila učenje vokabulara učenika drugog $i$ trećeg razreda, čime bi se ukazalo na prednosti uvođenja igre u nastavu engleskog jezika.

\section{TEORIJSKI OKVIR}

\subsection{Poznavanje vokabulara}

Da bi se ukazalo na značaj uticaja igre na učenje vokabulara, mora se prvo istaći da je poznavanje vokabulara od izuzetnog značaja za vladanje stranim jezikom jer samo ukoliko dobro poznaje reči i njihovu upotrebu u različitim kontekstima, osoba je sposobna da na pravi način iskaže ono što misli.

Uspešnost učenja vokabulara zavisi od mnogih faktora poput podsticaja i interesovanja za učenje, strpljivog nastavnika koji je spreman da smišlja nove aktivnosti 'u hodu' ako primeti da je učenicima dosadno, zanimljive učionice koja podstiče na rad i vežbi koje podižu motivaciju učenika i stvaraju osećaj da učenje jezika može biti zabavno i interesantno (Pilipović 2010), nastavnikovog i učenikovog poznavanja strategija učenja i sl. Jedan od važnih faktora uspešnog učenja vokabulara, takođe, podrazumeva i uvežbavanje novonaučenih reči na različite načine, i to: povezivanjem sa slikom, povezivanjem sa drugom reči, stvaranjem nove reči koristeći prefikse ili sufikse, popunjavanjem praznih polja, popunjavanjem ukrštenice, crtanjem ili dijagramima i igrama memorije (Pilipović 2010).

Značajan činilac koji doprinosi uspešnosti učenja vokabulara jeste nastavnikovo poznavanje faza učenja. Ukoliko poznaje faze kroz koje dete prolazi u toku učenja, nastavnik će biti u mogućnosti da lakše usmeri pažnju deteta, a materijal koji mu predstavlja učini zanimljivijim. Prema tome, učenik mlađeg uzrasta će lakše napamet naučiti značenje i izgovor pojedinačnih reči i nekih fraza, nego 
što je to slučaj kod starijih učenika. Sa druge strane, učenje kolokacija, metafora i polisemije treba uvesti u kasnijim fazama učenja (kod starijih učenika), ali u skladu sa njihovim kognitivnim razvojem. Prema Vilkeu (Vilke 1999, navedeno u Šekelj 2011), razdoblje od sedme do jedanaeste godine je najbolji period za učenje, jer dete u tom periodu ne traži objašnjenja, već jednostavno može da razume ono što čuje, vidi, oseti i prihvata svet oko sebe na onaj način na koji mu je izložen. Ukoliko dete uči strani jezik u ovom periodu, ono će sa lakoćom usvojiti pravilan izgovor samo ako je izloženo dobrom modelu (Šekelj 2011). U prilog tome ide i činjenica da su ovi učenici radoznali i da vole da pričaju o svojim iskustvima (Harmer 2001).

Najbolje bi bilo da se učenje izvodi u malim grupama, u opuštenoj i pozitivnoj atmosferi, uz zanimljive aktivnosti kao što su igre koje će deci učenje učiniti interesantnim i omogućiti da se izraze verbalno i motorički (Šekelj 2011). Kako su deca ovog uzrasta radoznala i aktivna, kad god je to moguće, treba im omogućiti da uče igrajući se, bilo da se radi o slušanju i izvođenju određenih radnji (npr. Simon says...) ili pisanju reči (npr. Hangman). Igra predstavlja i vizuelni i auditivni stimulus, a takođe podstiče govor i pokret čime značajno doprinosi učenju stranog jezika. Prezentovanje novog vokabulara će biti efikasnije ako se on prikaže kroz pesmu, igru, sliku i priču. Nova reč se može objasniti ili nastavnik može učenicima reći da pretpostave koji je prevod date reči, a zatim da zajedno dođu do pravog prevoda. U potrazi za pravim prevodom reči mogu pomoći i mimika, objašnjenja na stranom ili na maternjem jeziku, sinonimi, crtanje ili pokazivanje na objekte (Pilipović 2010). Da bi se reči upamtile, od velikog je značaja dobro koncipiran udžbenik sa jasno označenim rečima koje su od značaja za lekciju, zatim fokusiranje na vežbe vokabulara, kao i prikazivanje reči koje su se našle u određenom tekstu (McBrian 2011). Ove aktivnosti se mogu koristiti i za testiranje vokabulara. Testiranje vokabulara prema Peni Ur (Ur 1991) može se vršiti i korišćenjem pitanja sa više ponuđenih odgovora, izbacivanjem reči koja ne pripada, pisanjem rečenice, diktatima i prevodima.

\subsection{Pojam I KARAKTERISTIKe IGRE}

Igra ima veliku ulogu u razvoju ličnosti deteta. Ona predstavlja privlačnu aktivnost u kojoj dete uživa. Igrajući se, deca nemaju nameru da razviju neke sposobnosti, niti da postignu neki cilj, već samo da zadovolje unutrašnju potrebu za aktivnošću, a samim tim ne osećaju zamor u toku igre (Popović 1983). Dete se potpuno unosi u igru; ono se može dugotrajno igrati na isti način i na istom mestu, a ukoliko je pohvaljeno za ono što radi, ono će nastaviti da se igra i da ostvaruje još značajnije rezultate. Igra podstiče dete da radi i motiviše ga, a motivacija 
doprinosi dobrom subjektivnom osećaju i želji da se izvrši određena aktivnost (Nešić i Radomirović 2000).

Igra u nastavi je višestruko korisna. Ona motiviše dete i omogućava konkretizaciju gradiva, čime mu se približavaju vaspitno-obrazovni ciljevi. Igre koje se u ovom slučaju primenjuju za učenike ne moraju imati neke određene ciljeve, ali bi nastavnici u njima trebalo da vide jasno postavljene vaspitne i obrazovne ciljeve (Popović 1983).

Poboljšanje broja upamćenih reči može se ostvariti uvođenjem igre u nastavu. Učenje je lakše kroz igre jer se igrama smanjuje afektivni filter (nervoza i napetost), čime se olakšava usvajanje izraza (Richard-Amato 1988, navedeno u Azar 2012). Upotrebom igre menja se odnos učenika prema novim rečima. Kao prvo, učenici su opušteni, a samim tim lakše uče i brže pamte. Isto tako, u igrama najčešće postoji takmičarski duh koji je uvek interesantan učenicima i uvek ih motiviše da što bolje nešto urade (Azar 2012). Imajući sve to u vidu, uloga igara u učenju i u usvajanju vokabulara se ne može poreći. Međutim, da bi se postigao pravi uspeh i dobio najbolji rezultat učenja kroz igru, one moraju biti pažljivo odabrane i detaljno objašnjene učenicima (Azar 2012).

Ovim se ističe koliko je pravilan odabir igre važan. Odabir najčešće zavisi od nastavnika, koji mora da predviđa i planira ceo čas unapred, što je dugotrajan proces. Po rečima Hajen i Nga (Huyen \& Nga 2003), igre doprinose učenju jezika tako što daju mogućnost učeniku da koristi jezik, ali oni takođe ističu da treba posebno obratiti pažnju na odabir igara, tj. da igre koje se koriste moraju imati odgovarajuću svrhu. Nije svaka igra didaktička i nema svaka igra odgovarajući vaspitni cilj. Nastavnik treba da obrati pažnju na dobrobit tih igara za učenje, a da bi igra bila odgovarajuća, ona mora da bude primerena nivou znanja učenika, godinama i materijalu koji se obrađuje na času. Značajan faktor pri odabiru igre je i njeno trajanje, koje bi trebalo da se određuje prema samom odeljenju. Pravilnim odabirom igara mogu se ukloniti i nedostaci koje igra u nastavi može da ima (buka, žagor i sl.).

Igra pozitivno utiče i na pedagošku praksu nastavnika. Kada igra stvori pozitivnu atmosferu i kada su učenici motivisani, nastavniku je lakše da ispuni svoj nastavni cilj. Učenici bolje sarađuju, voljni su da urade zadatu aktivnost, a kao rezultat, motivisani su da uče (Yolageldili \& Arikan 2011). Šulc i Fišer (Schultz \& Fisher 1988) doprinose navedenim tvrdnjama ukazujući na to da kroz igru učenici uče ne znajući da uče. Oni ne razmišljaju o učenju kao nečemu što se mora, već koriste jezik spontano i prirodno. Čak i ako bi se u tradicionalnu nastavu uključio bar neki element igre, učenje bi postalo zanimljivije, a deca bi sa uživanjem učestvovala u aktivnostima.

Sve u svemu, iako se ne može sa sigurnošću tvrditi da igre svakom učeniku pomažu u istoj meri u savladavanju novog nastavnog materijala, moglo bi se 
reći da one svakako pomažu većini učenika u savladavanju nastavnog gradiva. Ukoliko je to moguće, treba ih uključiti u pedagošku praksu zato što su korisne za učenje, a rezultati su značajno bolji kod učenika koji su koristili igre u nastavi, nego kod onih koji nisu. Iz tog razloga, Ubermanova (Uberman 1998) zaključuje, da bi igra trebalo da se koristi u nastavi kao jedna od tehnika koja u velikoj meri doprinosi procesu usvajanja vokabulara.

\section{METODOLOGIJA ISTRAŽIVANJA UTICAJA IGRE NA UČENJE VOKABULARA}

Istraživanje na kojem se bazira rad ima za cilj da odgovori na pitanje: u kojoj meri učenje reči korišćenjem igre pomaže poznavanju tih reči? Da bi se pružio što precizniji odgovor postavljena je hipoteza i izvršeno je istraživanje. Hipoteza, koju istraživanje treba da potvrdi, glasi: korišćenje igre kao sredstva za učenje omogućava bolje poznavanje vokabulara (više reči, bolju upotrebu reči i sl.).

\subsection{VREME ISTRAŽIVANJA}

Celokupno istraživanje trajalo je četiri meseca i vršeno je u toku drugog polugodišta školske 2013/2014. godine. Prvih mesec dana, tačnije prvih osam časova u drugom polugodištu, predstavljao je period u kom su se učile nove reči i izrazi. Nastava se održavala dva puta nedeljno u trajanju od 45 minuta. Celokupno istraživanje obuhvatalo je osam časova za učenje i obnavljanje vokabulara i tri časa za testiranje naučenog.

\subsection{UČESNICI U ISTRAŽIVANJU}

Uzorak ispitanika činile su po dve grupe učenika drugog i trećeg razreda (četiri odeljenja približno istog nivoa znanja) Osnovne škole „Vuk Karadžić““ u Šapcu. Nivo znanja je određen srednjom ocenom iz prethodnog polugodišta i predstavlja početni nivo učenja engleskog jezika.

U svakom od razreda jedno odeljenje bilo kontrolna, a drugo eksperimentalna grupa. U celom istraživanju učestvovalo je 66 učenika, po 33 učenika u obe grupe. U drugom razredu u eksperimentalnoj grupi bilo je 8 dečaka i 8 devojčica, a u kontrolnoj 9 dečaka i 8 devojčica. U trećem razredu je u eksperimentalnoj grupi bilo 10 dečaka i 7 devojčica, dok je u kontrolnoj bilo 7 dečaka i 9 devojčica. Učenici koji rade po individualizovanom programu nisu uključeni u istraživanje. 


\subsection{PROCEDURA}

Podaci prikupljeni istraživanjem analizirani su kvantitativnom metodom obrade podataka, a celokupno istraživanje bilo je osmišljeno tako da se broj usvojenih reči merio korišćenjem tri testa. Testirani su učenici drugog i trećeg razreda na časovima redovne nastave. Pri obradi dobijenih podataka u istraživanju koristio se grafički prikaz za poređenje broja tačno rešenih primera u svakom zadatku, a zatim se vršila deskriptivna analiza dobijenih podataka.

U prvoj fazi, koja je sprovedena u prvih mesec dana drugog polugodišta, tačnije prvih osam časova, učenici eksperimentalne i kontrolne grupe drugog i trećeg razreda učili su nove reči. U obe grupe učenje novih reči sprovodilo se u toku celog časa. Materijal koji je obrađivan bio je baziran na udžbeniku predviđenom planom i programom za odgovarajući razred u Osnovnoj školi „Vuk Karadžić“ u Šapcu. Eksperimentalna grupa je učila nove reči uz pomoć igara, odabranih na osnovu materijala koji je predviđen programom i prilagođen cilju nastavne jedinice. Igre koje su korišćene u nastavi su:

- kinestetičke igre: Don't break the chain; Paper airplane game; Mime the text;

- igre u paru: Descriptions;

- $\quad$ gre u grupi: Board game; Mime the text; Chinese whispers; Prepositions game;

- govorne aktivnosti: Descriptions; Chinese whispers;

- igre slušanja: Guess who; Describing appearances \& characteristics of people; Chinese whispers;

- $\quad$ igre crtanja i pisanja: Describe and draw... the opposite; Hangman; Prepositions game;

- igre traženja: Draw the text; Cut up sentences kabadi;

- igre karticama: Bingo; Cut up sentences kabadi².

Učenici kontrolne grupe su pojmove učili čitanjem reči, ponavljanjem reči van konteksta (jedan po jedan učenik), pisanjem reči (u trećem razredu), pisanjem ili izgovaranjem prevoda; zatim su imali zadatak da napišu (treći razred) ili izgovore (drugi razred) rečenicu koja sadrži novonaučenu reč i sl. Materijal koji se koristio su udžbenici koji su već predviđeni programom za drugi i treći razred.

Druga faza predstavljala je testiranje stečenog znanja u cilju upoređivanja broja upamćenih pojmova u oba razreda. Učenicima svih grupa data su tri testa

2 Igre su preuzete iz knjige Language Activities for Teenagers; nastavničkog materijala Smart Junior 2: Teacher's book i sa sajta Games \& Activities for the ESL/EFL Classroom (http://iteslj.org/ games/). 
osmišljena na osnovu zadataka iz udžbenika predviđenih za drugi i treći razred. Testovi su osmišljeni na osnovu materijala predviđenog planom i programom pomenute osnovne škole, kao i na osnovu dodatnog materijala prilagođenog uzrastu učenika. Vokabular koji je testiran u drugom razredu obuhvatao je nazive delova tela i divljih životinja, kao i glagole 'have got', 'has got', 'can', 'run', 'swim', 'fly', 'talk' i 'jump'. Vokabular koji je testiran u trećem razredu odnosio se na nazive delova tela, životinja i predmeta u učionici, ali i na glagole 'have got', 'has got' i glagol 'to be', kao i predloge 'on', 'in', 'under', 'next to'.

Tipovi zadataka su varirali od prvog do trećeg testa. Zadaci u oba razreda su bili i otvorenog i zatvorenog tipa. Neki od zadataka otvorenog tipa uključivali su crtanje ili opisivanje, dok su zadaci zatvorenog tipa obuhvatali zadatke u kojima učenik treba da se opredeli za određeni odgovor (tačno - netačno, zaokruži slovo ili broj ispred tačnog odgovora, poveži i sl.). Težina zadataka se kretala uzlazno, od prvog testa kao najlakšeg do trećeg testa kao najtežeg.

Broj zadataka u testovina za drugi razred je sledeći: Test 1 (šest zadataka), Test 2 (pet zadataka) i Test 3 (pet zadataka). Zadaci u testovima za treći razred bili su raspoređeni na isti način, tj. Test 1 imao je šest zadataka, Test 2 pet, a Test 3, takođe, pet zadataka. Za svaki tačan odgovor u svim testovima bilo je moguće dobiti 1 (jedan) poen.

\subsection{Analiza PODATAKa}

Za svaki tačno urađen zadatak učenici su dobijali odgovarajući broj bodova, a sabiranjem ostvarenih poena za svaki zadatak dobijen je ukupan broj poena za svaki test, za svakog učenika. Dobijeni rezultati su prikazani tabelarno za svako odeljenje, kao i za svaku grupu (eksperimentalnu i kontrolnu). Rezultati su, takođe, prikazani i za svakog učenika ponaosob i to na osnovu dobijenih bodova u svakom zadatku. Kako bi se obezbedila anonimnost učesnika, umesto imena učenika iz eksperimentalnog odeljenja korišćena su abecedna slova od A do P, za drugi, odnosno, od A do R, za treći razred, a za učenike kontrolne grupe rimski brojevi (od I do XVII) za drugi, odnosno, od I do XVI za treći razred. Radi boljeg prikaza rezultata, Grafikonom 1 (drugi razred) i Grafikonom 2 (treći razred), predstavljen je uporedni prikaz rezultata za dva odeljenja istog razreda.

\section{REZULTATI}

Kako igra nije korišćena u nastavi u toku prvog polugodišta svih razreda koji su učestvovali u istraživanju, dat je tabelarni prikaz prosečne ocene predmeta 
engleskog jezika u odeljenjima u kojima se vršilo istraživanje, na kraju prvog polugodišta tekuće školske 2013/2014. godine.

\begin{tabular}{|l|l|l|l|}
\hline \multicolumn{2}{|l|}{} & Broj učenika & Prosečna ocena \\
\hline \multirow{2}{*}{ Učenici 2. razreda } & $\begin{array}{l}\text { eksperimentalna } \\
\text { grupa }\end{array}$ & 16 & 4,16 \\
\cline { 2 - 4 } & kontrolna grupa & 17 & 3,95 \\
\hline \multirow{2}{*}{ Učenici 3. razreda } & $\begin{array}{l}\text { eksperimentalna } \\
\text { grupa }\end{array}$ & 17 & 3,71 \\
\cline { 2 - 4 } & kontrolna grupa & 16 & 3,51 \\
\hline Ukupno & 66 & \\
\hline
\end{tabular}

Tabela 1 - Prikaz prosečne ocene engleskog jezika

Nakon urađenih i pregledanih testova i rezultata testova prikazanih u Tabelama 2 i 3 za drugi, odnosno Tabelama 4 i 5 za treći razred, izračunata je i srednja ocena za svaki test, što je i prikazano na Grafikonu 1 za drugi razred i Grafikonu 2 za treći razred.

$\mathrm{Na}$ osnovu rezultata prikazanih na obe tabele i na osnovu poređenja srednjih ocena u eksperimentalnoj i kontrolnoj grupi, utvrđeno je da uključivanje pokreta i igara u nastavu olakšava savladavanje vokabulara. Ovim se potvrđuje da korišćenje igre kao sredstva za učenje omogućava bolje poznavanje vokabulara (više reči, bolju upotrebu reči i sl.) što je i bila postavljena hipoteza istraživanja.

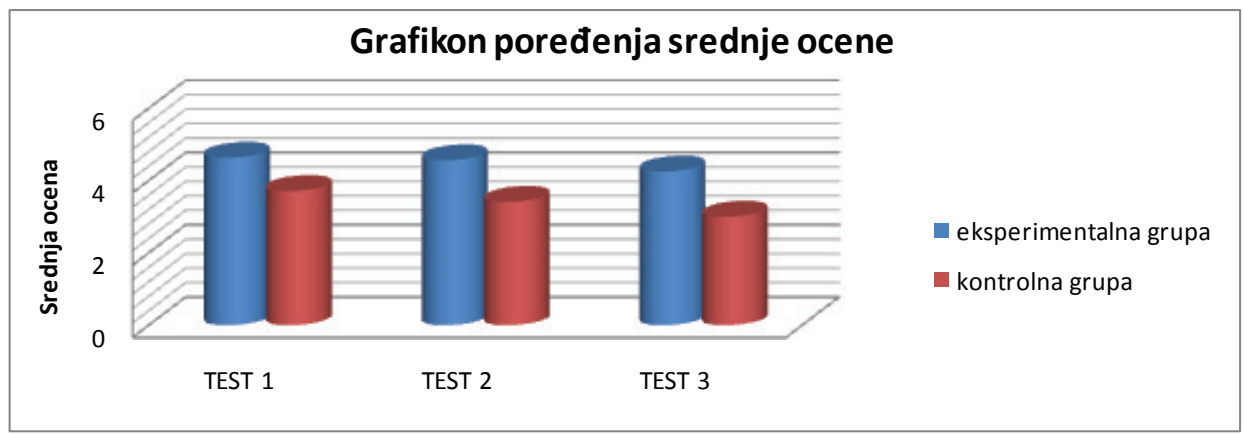

Grafikon 1. Poređenje srednje ocene prvog, drugog i trećeg testa eksperimentalne $i$ kontrolne grupe drugog razreda 


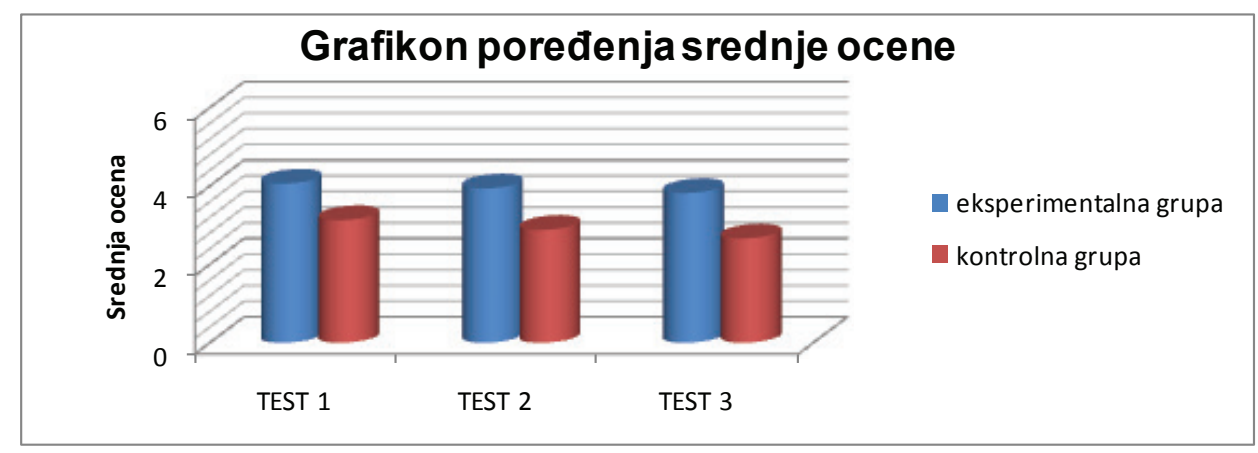

Grafikon 2. Poređenje srednje ocene prvog, drugog i trećeg testa eksperimentalne i kontrolne grupe trećeg razreda

\section{DISKUSIJA}

\subsection{DRUGI RAZRED}

Prikazani rezultati nam pokazuju koliko su učenici bili uspešni u rešavanju zadataka.

Rezultati sva tri testa u drugom razredu pokazuju da je nakon igara poput Bang, bang, Board game i Simon says unapređena veština slušanja jer su učenici eksperimentalne grupe, zahvaljujući pokretu i igri lakše upamtili reči. Ovakav rezultat se može objasniti činjenicom da učenici drugog razreda u ovom periodu tek uče da pišu latinicu, te je najbolje osloniti se na aktivnosti slušanja, a kako je njihova koncentracija slaba i brzo gube pažnju, igre predstavljaju pravu aktivnost koja im olakšava usvajanje reči.

Uticaj igara koje su korišćene pri učenju glagola kretanja i glagola 'can' (Don't break the chain, Paper airplane game), kao i igre koja je kombinovala nazive životinja sa glagolom 'can' (Board game) u drugom razredu, doprinele su da veština prepoznavanja napisane reči bude znatno veća u eksperimentalnoj nego u kontrolnoj grupi. Isti uticaj se može videti i u zadatku u kom se zahtevalo čitanje reči i povezivanje sa grafičkom prezentacijom, gde su učenici eksperimentalne grupe, usled aktivnog korišćenja naziva delova tela, njihovog crtanja i pokazivanja, kroz igre kao što su Describe and draw... the opposite i Guess who, mnogo bolje upamtili na koji deo tela se određena reč odnosi, za razliku od učenika koji su nazive delova tela ponavljali van konteksta bez povezivanja sa stvarnošću. Učenici eksperimentalne grupe kojima je svaka reč predstavljena kroz pokret, sli- 
čice i kojima je data prilika da te reči pročitaju i izgovore bila je mnogo uspešnija u prepoznavanju glagola i povezivanju glagola sa sličicom.

Veština pisanja i povezivanja lica sa glagolom, iako se promena glagola po licima nije isticala na času, pokazala se znatno uspešnijom kod učenika eksperimentalne grupe u sva tri testa. Jedna od igara koja je doprinela znanju učenika eksperimentalne grupe je Guess who koja je pomogla učenicima eksperimentalne grupe da lakše savladaju materiju i ispravno povežu zamenice 'he' i 'she' sa pravilnim oblikom glagola 'have', što nije bio slučaj u kontrolnoj grupi.

Posmatrano u globalu, učenici eksperimentalne grupe drugog razreda su pokazali bolje znanje na sva tri testa, a njihovi rezultati su izloženi u tabeli koja sledi (Tabela 2). Učenici su, u većini slučajeva, dobijali iste ocene na sva tri testa ali je primećen blaži pad ocene koji može biti posledica razlike u težini zadataka $u$ testovima. Rezultati testova svakog učenika drugog razreda prikazani su u Tabeli 2, a data je i srednja ocena svih testova.

\begin{tabular}{|c|c|c|c|c|}
\hline \multicolumn{5}{|c|}{ UČENICI EKSPERIMENTALNE GRUPE DRUGOG RAZREDA (16) } \\
\hline br & Šifra & Test 1 & Test 2 & Test 3 \\
\hline 1. & A & 5 & 5 & 5 \\
\hline 2. & B & 5 & 5 & 5 \\
\hline 3. & $\mathrm{C}$ & 5 & 5 & 5 \\
\hline 4. & $\mathrm{D}$ & 5 & 5 & 5 \\
\hline 5. & $\mathrm{E}$ & 5 & 4 & 4 \\
\hline 6. & $\mathrm{~F}$ & 5 & 5 & 5 \\
\hline 7. & $G$ & 5 & 5 & 5 \\
\hline 8. & $\mathrm{H}$ & 4 & 4 & 4 \\
\hline 9. & I & 5 & 4 & 3 \\
\hline 10. & $\mathrm{~J}$ & 5 & 5 & 4 \\
\hline 11. & K & 5 & 4 & 4 \\
\hline 12. & $\mathrm{~L}$ & 3 & 4 & 4 \\
\hline 13. & $\mathrm{M}$ & 3 & 4 & 3 \\
\hline 14. & $\mathrm{~N}$ & 4 & 4 & 4 \\
\hline 15. & $\mathrm{O}$ & 5 & 5 & 4 \\
\hline 16. & $\mathrm{P}$ & 5 & 5 & 4 \\
\hline & SREDNJA OCENA & 4,63 & 4,56 & 4,25 \\
\hline
\end{tabular}

Tabela 2. Prikaz ocena po testovima i srednje ocene učenika drugog razreda eksperimentalne grupe 
Učenici kontrolne grupe drugog razreda pokazali su lošiji rezultat. Upoređujući rezultate sva tri testa, nije se primetilo poboljšanje. Uočljiv je i pad srednje ocene testa, kako je materijal postajao teži, a uočljiva je i razlika u srednjim ocenama testova kontrolne i eksperimentalne grupe.

Uzimajući u obzir činjenicu da su učenici kontrolne grupe nazive delova tela ponavljali van konteksta bez povezivanja sa stvarnošću, jasno je da su u sva tri testa rezultati bili lošiji. Učenici su, pored grešaka u zadacima koji su se odnosili na pisanje naziva delova tela, pravili greške i u čitanju naziva, a neki čak nisu uspevali da upamte na koji deo tela se određena reč odnosi kada je čuju.

Učenici iz kontrolne grupe ostvarili su lošiji rezultat u zadacima u kojima su testirani glagoli kretanja i glagol 'can', kao i kombinacija naziva životinja sa glagolom. Neki od učenika nisu pokazivali napredak ili su stagnirali na sva tri testa.

Nešto bolji uspeh, u odnosu na druge zadatke, pokazao se u zadacima gde se od učenika zahtevalo da čitaju reči i povezuju ih sa grafičkom prezentacijom. Takav tip zadataka je u istoj meri uspešno urađen na sva tri testa. Učenici kontrolne grupe su uspešno rešavali zadatke čiji je cilj bilo pisanje ili prepisivanje; međutim, ukoliko je cilj takvih zadatka bio formiranje rečenica sa ispravnom gramatičkom konstrukcijom, kroz sva tri testa uočene su poteškoće učenika da povežu zamenice 'he' i 'she' sa pravilnim oblikom glagola 'have'.

Može se uočiti da se kod određenog broja učenika javlja pad ocene, a da je samo tri učenika zadržalo istu ocenu na sva tri testa. Prikaz rezultata testova za svakog učenika kontrolne grupe je dat u Tabeli 3 .

\begin{tabular}{|l|l|l|l|l|}
\hline \multicolumn{5}{|c|}{ UČENICI KONTROLNE GRUPE DRUGOG RAZREDA (17) } \\
\hline Br. & \multicolumn{1}{|c|}{ Šifra } & Test 1 & Test 2 & \multicolumn{1}{c|}{ Test 3 } \\
\hline 1. & I & 5 & 5 & 4 \\
\hline 2. & II & 5 & 5 & 5 \\
\hline 3. & III & 4 & 5 & 4 \\
\hline 4. & IV & 3 & 4 & 4 \\
\hline 5. & V & 3 & 4 & 4 \\
\hline 6. & VI & 4 & 4 & 3 \\
\hline 7. & VII & 4 & 4 & 4 \\
\hline 8. & VIII & 4 & 3 & 3 \\
\hline 9. & IX & 3 & 2 & 1 \\
\hline 10. & X & 4 & 3 & 1 \\
\hline
\end{tabular}




\begin{tabular}{|l|l|l|l|l|}
\hline 11. & XI & 3 & 1 & 1 \\
\hline 12. & XII & 3 & 1 & 2 \\
\hline 13. & XIII & 4 & 5 & 5 \\
\hline 14. & XIV & 4 & 3 & 3 \\
\hline 15. & XV & 4 & 3 & 2 \\
\hline 16. & XVI & 3 & 3 & 3 \\
\hline 17. & XVII & 3 & 3 & 2 \\
\hline \multicolumn{2}{r|}{ SREDNJA OCENA } & 3,71 & 3,41 & 3,00 \\
\hline
\end{tabular}

Tabela 3. Prikaz ocena po testovima i srednje ocene učenika drugog razreda kontrolne grupe

Na osnovu svih navedenih podataka, jasno se može uočiti da je eksperimentalna grupa postigla bolji uspeh u učenju novih reči, što je ustanovljeno na osnovu boljih rezultata na testovima. Razlika u srednjoj oceni ove dve grupe, jasnije se može uočiti na Grafikonu 1 (Poglavlje 4).

\subsection{TREĆI RAZRED}

Uspeh učenika trećeg razreda donekle se poklapa sa uspehom u drugom razredu. Veština pisanja koja je kod učenika eksperimentalne grupe učena korišćenjem igara Hangman, Prepositions game i Descriptions pokazala se znatno uspešnijom u eksperimentalnoj grupi. Učenici su na sva tri testa pokazali da su savladali materijal predviđen planom i programom za taj čas. Čak i učenici koji nisu dovoljno savladali pisanje naziva zadatog pojma, umeli su da izgovore njegov naziv ili da prepoznaju predmet.

Igre koje su bile od pomoći za razvoj veštine slušanja, kao što su Describing appearances \& characteristics of people, Descriptions, Bingo i Chinese whispers, pomogle su učenicima u eksperimentalnoj grupi da u sva tri testa pokažu da su u velikoj meri umeli da prepoznaju nazive, što im je pomoglo i u pisanju odgovarajućih naziva. Veliki značaj ovih igara uočava se kako u čitanju naziva delova tela tako i u njihovom povezivanju sa slikom.

Učenici eksperimentalne grupe su takođe pokazali zavidno znanje u pravilom korišćenju oblika glagola 'to be' u zavisnosti od roda i broja. Ova grupa učenika je glagol 'to be' obrađivala i utvrđivala putem igara Draw the text i Cut up sentences kabadi. Veština čitanja se, takođe, pokazala uspešnijom u eksperimentalnoj grupi i to u korišćenju predloga za mesto u čijem je učenju značajan uticaj 
imala igra Prepositions game. Većina učenika je sa lakoćom koristila predloge na ispravnom mestu u rečenici i pisala ih na odgovarajuća mesta u zadatom tekstu.

Rezultati koje su postigli učenici eksperimentalne grupe trećeg razreda prikazani su u Tabeli 4.

\begin{tabular}{|l|l|l|l|l|}
\hline \multicolumn{5}{|c|}{ UČENICI EKSPERIMENTALNE GRUPE TREĆEG RAZREA (17) } \\
\hline Br. & \multicolumn{1}{|c|}{ Šifra } & \multicolumn{1}{|c|}{ Test 1 } & Test 2 & Test 3 \\
\hline 1. & A & 5 & 5 & 5 \\
\hline 2. & B & 5 & 5 & 5 \\
\hline 3. & C & 5 & 5 & 5 \\
\hline 4. & D & 5 & 4 & 4 \\
\hline 5. & E & 5 & 5 & 5 \\
\hline 6. & F & 5 & 5 & 5 \\
\hline 7. & G & 5 & 4 & 3 \\
\hline 8. & H & 5 & 5 & 5 \\
\hline 9. & I & 4 & 4 & 4 \\
\hline 10. & J & 4 & 4 & 3 \\
\hline 11. & K & 4 & 3 & 4 \\
\hline 12. & L & 4 & 5 & 4 \\
\hline 13. & M & 3 & 4 & 3 \\
\hline 14. & N & 3 & 2 & 2 \\
\hline 15. & O & 3 & 2 & 4 \\
\hline 16. & P & 2 & 3 & 2 \\
\hline 17. & Q & 2 & 2 & 2 \\
\hline & SREDNJA OCENA & 4,06 & 3,94 & 3,82 \\
\hline
\end{tabular}

Tabela 4. Prikaz ocena po testovima i srednje ocene učenika tré́eg razreda eksperimentalne grupe

S obzirom da su učenici nazive delova tela, učionice i slično učili ponavljanjem izgovorenog ili pisanjem i prepisivanjem rečenica, naučeni materijal je bio lošije savladan. Određeni broj učenika, pored toga što u dovoljnoj meri nije savladao pisanje naziva, nije umeo ni da pravilno izgovori naziv za zadati pojam. Učenicima je bilo teško da upamte i predloge i da ih pravilno upišu u rečenice (jedna od najčešćih grešaka u sva tri testa). 
Veliki problem za učenike kontrolne grupe bila je i pravilna upotreba glagola 'to be' i njegov tačan oblik u odnosu na lice i broj. Učenici su pokušavali da nauče napamet kada se koji oblik koristi, što je kod jednog broja učenika dovelo do potpune zabune i nepravilnog korišćenja glagola. Ipak, određeni broj učenika je imao uspeha u savladavanju ovog glagola iako je on učen korišćenjem vežbi sa ponavljanjem i drilova.

Kod učenika kontrolne grupe se može primetiti značajniji pad ocene, kao i to da je samo tri učenika zadržalo istu ocenu na sva tri testa. Rezultati testova su prikazani u Tabeli 5.

\begin{tabular}{|l|l|l|l|l|}
\hline \multicolumn{4}{|c|}{ UČENICI KONTROLNE GRUPE TREĆEG RAZREDA (16) } \\
\hline Br. & \multicolumn{1}{|c|}{ Šifra } & \multicolumn{1}{|c|}{ Test 1 } & Test 2 & \multicolumn{1}{c|}{ Test 3 } \\
\hline 1. & I & 5 & 5 & 4 \\
\hline 2. & II & 5 & 4 & 5 \\
\hline 3. & III & 4 & 3 & 3 \\
\hline 4. & IV & 4 & 4 & 4 \\
\hline 5. & V & 4 & 3 & 3 \\
\hline 6. & VI & 4 & 4 & 4 \\
\hline 7. & VII & 4 & 3 & 1 \\
\hline 8. & VIII & 3 & 3 & 1 \\
\hline 9. & IX & 3 & 2 & 3 \\
\hline 10. & X & 3 & 3 & 2 \\
\hline 11. & XI & 3 & 3 & 3 \\
\hline 12. & XII & 2 & 2 & 1 \\
\hline 13. & XIII & 2 & 1 & 1 \\
\hline 14. & XIV & 2 & 3 & 2 \\
\hline 15. & XV & 1 & 1 & 2 \\
\hline 16. & XVI & 1 & 2 & 3 \\
\hline & SREDNJA OCENA & 3,13 & 2,88 & 2,66 \\
\hline
\end{tabular}

Tabela 5. Prikaz ocena po testovima i srednje ocene učenika trećeg razreda kontrolne grupe

Nakon analize svih testova moglo bi se zaključiti da je korišćenje igre imalo značaj za usvajanje reči. Primetna je bila i frustracija kod učenika kontrolne gru- 
pe koji teže shvataju šta se od njih traži u zadacima i teže se prisećaju pojmova naučenih na času. Poređenje srednjih ocena sva tri testa dato je na Grafikonu 2 (Poglavlje 4).

\section{ZAKLJUČAK}

Igra u nastavi može biti moćno sredstvo učenja i poboljšanja nastavnog procesa. Kroz nju se budi interesovanje i motivacija učenika čime se i podstiče želja za učenjem. To je potvrđeno i istraživanjem na kome se temelji ovaj rad. Na osnovu poređenja rezultata dobijenih testiranjem kontrolne grupe u kojoj se primenjivala tradicionalna nastava i rezultata ostvarenih u eksperimentalnoj grupi, gde se primenjivala igra kao sastavni deo nastavnog plana, moglo bi se zaključiti da je eksperimentalna grupa bila dosta uspešnija. Učenici iz ove grupe su znanje stekli na lakši i jednostavniji način, uz dosta smeha, kroz igru, uz veće angažovanje na času, davanjem ideja, maštanjem i aktivnim uključivanjem u nastavu, a to je ono što najviše nedostaje tradicionalnoj nastavi. Ovakav način sticanja znanja omogućio im je duže i lakše pamćenje pojmova. Usled pokreta, kao aktivnosti svojstvene uzrastu ispitanika, većeg broja ponavljanja pojmova tokom igara, opuštene atmosfere i smanjenog afektivnog filtera, manje dominantnosti nastavnika i sl., učenici eksperimentalne grupe su učili na opušten i zabavan način. Igre su im omogućile i povezivanje naučenog sa ranijim znanjem, usled čega se naučeno duže pamtilo.

Uključivanje dece u nastavu značajno doprinosi pomeranju fokusa sa nastavnika na učenika. Nastavnik uvek mora imati na umu koji je cilj uvođenja određene igre u nastavu, koja je prava igrovna aktivnost $i$ da li ona odgovara nastavnom cilju, kao i da uvek bude spreman da menja aktivnosti i da ih usmerava ka nastavnom cilju. Sve ovo je neophodno, jer će u suprotnom igra od korisne aktivnosti koja podstiče na rad i učestvovanje, postati neefikasna i neproduktivna. $\mathrm{Na}$ osnovu rezultata istraživanja, moglo bi se zaključiti da korišćenje igre kao nastavne tehnike omogućava uspešnije učenje vokabulara (više reči, tačniju upotrebu reči i sl.). Ne treba zanemariti ni činjenicu da igra u velikoj meri doprinosi unapređenju motivacije za učenje, kao i da uvećava želju učenika da učestvuju u aktivnostima u toku učenja stranog jezika.

\section{LITERATURA}

Azar, A. S. (2012). "The Effect of Games on EFL Learners' Vocabulary Learning Strategies". International Journal of Basic and Applied Science 1: 252-256. 
Games \& Activities for the ESL/EFL Classroom. A Project of The Internet TESL Journal. Pristupljeno 12. 3. 2014. URL: $<$ http://iteslj.org/games $/>$

Harmer, J. (2001). The Practice of English Teaching, 3rd Ed. Harlow: Pearson Education.

Huyen, N. T. T. \& Nga, K. T. T. (2003). "The effectiveness of learning vocabulary through games". Asian EFL Journal. Pristupljeno 29. 5. 2014. URL: $<$ http:// asian-efl-journal.com/dec 03 vn.pdf>

Ivić, I., Pešikan, A. \& Antić, S. (2001). Aktivno učenje. Beograd: Institut za psihologiju.

Kopas-Vukašinović, E. (2006). "Uloga igre u razvoju dece predškolskog i mlađeg školskog uzrasta“. Zbornik Instituta za pedagoška istraživanja 38(1): 174189.

Lindstromberg, S. (2004). Language Activities for Teenagers. Cambridge: Cambridge University Press.

McBrian, R. (2011). Teaching Vocabulary to ESL Students. Pristupljeno 12. 2. 2014. URL: $<$ http://eric.ed.gov/?id=ED523679>

Mirković, J. (2007). "Igrolika nastava“. Obrazovna tehnologija 1-2: 65-68.

Mitchell, H. Q. (2009). Smart Junior 2: Teacher`s book. London: MM publications.

Nešić, B. \& Radomirović, V. (2000). Osnove razvojne psihologije. Jagodina: Učiteljski fakultet.

Pilipović, V. (2010). The Basics of English Language Teaching. Novi Sad: Unija fakulteta jugoistočne Evrope : Fakultet za pravne i poslovne studije : Prometej.

Popović, T. (ur.) (1983). Igra i igračke. Beograd: Zavod za udžbenike i nastavna sredstva.

Richard-Amato, P. (1988). "Making It Happen: Interactions in the Second Language Classroom", In Azar, A. S. (2012). The Effect of Games on EFL Learners' Vocabulary Learning Strategies. International Journal of Basic and Applied Science 1: 252-256.

Schultz, M. \& Fisher, A. (1988). Interacting in the Language Classroom. Games for All Reason. Massachusetts: Addison-Wesley Publishing Company.

Sigurðardóttir, S. D. (2010). The use of games in the language classroom. Menntavísindasvið: Kennaradeild, grunnskólakennarafræði. Pristupljeno 12. 3. 2014. URL: <http://skemman.is/stream/get/1946/6467/13457/1/ Sigridurdogg2010.pdf $>$

Šekelj, A. (2011). "Usvajanje vokabulara engleskog jezika kao stranog jezika u ranoj školskoj dobi“. Tabula 9: 200-211. 
Uberman, A. (1998). "The use of games for vocabulary presentation and revision". Forum 36(1): 20-27. Pristupljeno 12. 3. 2014. URL: $<$ http://dosfan.lib.uic. edu/usia/E-USIA/forum/vols/vol36/no1/p20.htm>

Ur, P. (1991). A Course in Language Teaching. Cambridge: Cambridge University Press.

Vilke, M. (1991). "Vaše dijete i jezik", u Šekelj, A. (2011). Usvajanje vokabulara engleskog jezika kao stranog jezika u ranoj školskoj dobi. Tabula 9: 200211.

Yolageldili, G. \& Arikan, A. (2011). "Effectiveness of using games in teaching grammar to young learners". Elementary Education Online 10(1): 219229, Pristupljeno 12. 3. 2014. URL: <http://eric.ed.gov/?id=ED527862>

\section{Tamara M. Alfirević}

\section{THE INFLUENCE OF GAMES ON ENGLISH LANGUAGE VOCABULARY LEARNING OF SECOND AND THIRD GRADE ELEMENTARY SCHOOL STUDENTS}

\section{Summary}

Different approaches to teaching foreign languages dictated different ways of learning vocabulary. Vocabulary was taught for a long time through translation or memorization of a series of isolated words. Today, it is considered important that children participate in class and that the process of learning is based on students' satisfaction, which in turn increases their motivation for learning. By using games in teaching, vocabulary is acquired in an interesting way, and allows better memorization of vocabulary items.

The empirical part of the paper is a presentation of the survey conducted among elementary school students in Šabac. The research included two groups of second and third grade students, one of which was the control group and the other was the experimental group. The aim of this research is to determine whether learning vocabulary through games contributes to vocabulary items being memorized for a longer period of time. The findings show that the game facilitates vocabulary learning and allows spontaneous and creative expression.

Key words: vocabulary, game, the English language, elementary school. 